\title{
Age 40, Year of the 'Signature Work': The Cases of Cage, Reich and Adams
}

\author{
Kyle Fyr \\ College of Music, Mahidol University, \\ 25/25 Phutthamonthon Sai 4 Road Salaya, \\ Phutthamonthon Nakhonpathom, 73170 Thailand \\ e-mail: kyle.fyr@mahidol.ac.th
}

Published online: 16 June 2017

\begin{abstract}
The 'signature works' of John Cage, Steve Reich and John Adams-4'33", Music for Eighteen Musicians and Nixon in China, respectively - are widely considered landmarks in recent American music and also parallel one another in a fascinating way, as the completion of each signature work dates from the year its composer turned forty. This article investigates the role of each signature work in its composer's stylistic development, studies the factors that led to the works' creation, discusses what made these works so innovative, and examines common threads among the three composers' career arcs in order to explore how their fortieth years became so pivotal in the context of their overall output. Is this agerelated correspondence just an extraordinary coincidence or might it suggest broader correlations? Studies on age and creative achievement by psychologist Dean K. Simonton and others suggest that such correlations in fact exist and that the age of forty may be particularly significant, thus corroborating the significance of the intriguing age-related parallels among the careers of Cage, Reich and Adams.
\end{abstract}

Keywords: age and creative achievement, John Adams, John Cage, musical style analysis, Steve Reich

\section{Introduction}

The careers of John Cage, Steve Reich and John Adams parallel each other in a striking way: each composer completed what can be convincingly called his 'signature work' in the year he turned forty. Cage unveiled his revolutionary composition 4'33' in his fortieth year, Reich turned forty in the same year he completed his landmark work Music for Eighteen Musicians, and Adams likewise turned forty in the year he produced his ground-breaking opera Nixon in China. In light of this remarkable correspondence, this article examines the role each signature 
work played in its composer's aesthetic and stylistic development, investigates the factors that led to the works' creation, discusses what made these works so innovative and explores common threads among the three composers' career arcs as a means of demonstrating how their fortieth years became so pivotal in the context of their overall output. In order to contextualise the intriguing age-related parallels among the careers of Cage, Reich and Adams, this article first surveys noteworthy studies in the field of psychology by Dean K. Simonton and others which suggest that such correlations between age and defining artistic achievements are more than mere coincidence and that the age of forty may hold particular significance in this regard.

Just what makes a signature work? For the purposes of this study, each of the works in question must fit all of the following criteria: 1) it is a work for which the composer is widely recognised; 2) it represents a significant turning point in the composer's career; 3 ) it represents a sort of culmination of the composer's previous work; 4) it is a composition whose style and/or techniques have exerted a lasting influence on the composer's subsequent works; 5) it is a composition that has exerted significant influence on American art music and on Western art music in general during the post-World War II era. Supplementing these five criteria, the signature work label is most compellingly applied when the composer personally acknowledges the piece's significance or at least holds it in high esteem. Although there is certainly a degree of subjectivity involved in classifying any piece as a composer's signature work, the criteria listed here effectively limit which compositions may be persuasively placed into this category.

\section{Studies on the relationship of age and creative achievement}

The question of whether creativity and achievement are somehow related to age is an avenue of inquiry with a long history. Perhaps the earliest scholarly study was George M. Beard's Legal Responsibility in Old Age, which dates back to 1874. Based on a survey of 450-500 historical 'high achievers', Beard determined that "men are at their best at the time when enthusiasm and experience are most evenly balanced", deducing that "this period, on the average, is from 38 to 40" (Beard, 1874 , p. 8). While Simonton notes that Beard's theory "is more conceptual than mathematical and hence leads to no precise predictions that can be subjected to empirical tests", he nevertheless grants that in spite of its simplicity, the study has a respectable amount of explanatory power (Simonton, 1988, p. 260). Harvey C. Lehman then presented a much more rigorous study in his influential 1953 book, Age and Achievement, summarizing roughly three decades' worth of research on this issue (Lehman, 1953). Lehman's most noteworthy conclusion, after studying the relationship of age and achievement in a wide variety of professions, was that all endeavours surveyed displayed a single-peak age curve in relation to achievement. Simonton notes that Lehman's age curves, which were derived from individuals' landmark contributions, brought him criticism from some other scholars, perhaps unsurprisingly given the implication that achievement would generally deteriorate in 
the later years of individuals' careers (Simonton, 1988, p. 256). Some of Lehman's critics, most notably Wayne Dennis, disputed the method of tabulating outstanding contributions instead of focusing on total productive output (Dennis, 1966, pp. 1-8). Later research by Simonton would suggest a consistently positive linkage between quality and quantity of output, however, thus mitigating the effect of these criticisms (Simonton, 1988, p. 254).

Recently, Dean K. Simonton has published prolifically on this subject, studying the relationships between age and career achievement across a wide variety of disciplines. In a study highly pertinent to the examination of the signature works of Cage, Reich and Adams presented in this article, Simonton examined the careers of 120 selected composers, ranging chronologically from the sixteenth century to the early twentieth century, yielding a representative sample of Western art music composers whose careers provided data from which broad trends regarding age and creative achievement could be extrapolated (Simonton, 1991). Simonton's selected composers' output was analysed according to two measures: themes and works. In terms of themes, which Simonton defined as the melody, motive, or subject that constitutes a building block of a composition, the mean age at which the composers studied achieved their 'best hit' or most acclaimed theme was found to be 39.68. As per the works measure, the mean age at which the composers studied produced their 'best hit' or most illustrious composition was found to be 40.78, a remarkably close concordance with the themes measure (Simonton, 1991, pp. 834-835). Furthermore, Simonton's study corroborated Lehman's most noteworthy conclusion: that creative endeavours tend to display a single-peak age curve in relation to achievement (Simonton, 1988, p. 251). In addition to these thought-provoking conclusions, Simonton's study is notable for its attention to potentially problematic details, such as compensating for the 'noise' introduced by the prolific yet short-lived careers of composers such as Mozart and Schubert. While Simonton acknowledges that there are of course individual variations within any sample, his study intriguingly suggests that composers' fortieth years tend, on average, to produce the signature works for which their careers are most often associated.

The fact that Cage, Reich and Adams all completed their signature works in the years they turned forty raises a provocative question: are these striking agerelated parallels simply a coincidence or might they be precise exemplars of the broader correlations regarding age and creative achievement indicated in studies such as Simonton's? The following inquiries into the career arcs and signature works of Cage, Reich and Adams endeavour to shed light on the factors behind these remarkable correspondences and in turn reveal some noteworthy similarities in the composers' aesthetic and stylistic development. 


\section{The Case of John Cage (1912-1992)}

\section{Leading up to 1952}

The early career of John Cage followed a fascinating arc, beginning with a desire to find new sounds, followed by captivation with the very antithesis of sound (silence), which in turn fed into a near complete relinquishment of compositional control in favour of chance and indeterminacy. Cage's search for new sounds was exemplified by his Sonatas and Interludes of 1946-48 (age 34-36), a work for prepared piano widely acknowledged as the finest composition of his early period (Pritchett, 1993; Bernstein, 2002; Nicholls, 2007). This work is highly organised not only in terms of the sequence of pieces within it but also in its sophisticated proportional structures - a means of compositional organisation that Cage often employed, beginning with 1939's First Construction (in Metal). The piano preparation is also quite intricate; forty-five pitches are altered by placing various materials inside the piano, in turn creating exotic, mesmerizing sounds that often evoke the sounds of a percussion ensemble more than a piano. The Sonatas and Interludes represented a high point of development for Cage, both in terms of technique and emotional expressivity. Because of the variations in sounds from piano to piano, however, Cage quickly realised that this type of composition represented a certain lack of control, a situation that originally disconcerted him but later pleased him greatly (Bernstein, 2002, p. 84).

The Sonatas and Interludes brought Cage's aesthetics into greater focus yet also provided a springboard to further developments. In the late 1940s and 1950s, Cage became increasingly fascinated with Zen Buddhism and the I-Ching and also became renowned for his lectures, a number of which were later collected in his landmark 1961 book Silence. The frequently cited 'Lecture on Nothing' from 1950 not only outlines Cage's nascent philosophies about detachment and nonpossession, but is structured like a musical composition. James Pritchett posits that the lecture is therefore "no longer just a conduit for information, but both an explanation and a concrete demonstration of ideas" (Pritchett, 1993, p. 55). The most significant turning point in Cage's evolution, however, came in 1952, roughly five years after composing Sonatas and Interludes. It was then, in his fortieth year, that Cage presented his most well-known demonstration of ideas about 'nothing' with the 'silent piece' 4'33".

\section{4'33" and beyond}

David Nicholls posits that the shocking boldness of Cage's 4'33"' has made it "without doubt [his] best-known and least-understood composition ... his major aesthetic statement and the focus of much uncomprehending criticism" (Nicholls, 2007 , p. 58). For a pianist to walk on stage and then 'not play' seems a liberating expansion of musical possibilities on one hand but paradoxically a total renunciation of what constitutes a musical work on the other. Michael Broyles notes that 4'33'” predictably caused a stir and although audiences are often still not sure whether to 
take it seriously, Cage in fact took the work very seriously, calling it his most important piece (Broyles, 2004, p. 185).

Cage's ideas for 4'33" apparently originated in 1948 and took about four years to cohere into their eventual form. The revelatory event that ultimately led him to compose 4'33" was his experience in an anechoic chamber at Harvard University in either 1951 or 1952; Pritchett (1993) says the event occurred in 1951, but Nicholls (2007) says it occurred in 1952, a discrepancy most likely due to Cage's own conflicting recollections of the date. In any case, Cage fully expected to experience silence when entering the soundproof room, but found that he actually heard two sounds: his nervous system and his blood circulating (Cage, 1967, p. 134). Nicholls notes that Cage thus had to "follow through to its conclusion the logic of accepting ... the plethora of ambient unintended sounds that constantly surround us" (Nicholls, 2007, p. 59), what Stephen Whittington suggests might be termed a sort of 'borrowed soundscape' (Whittington, 2013, p. 14). By following this logic in 4'33'", Cage made an artistic statement that seriously questioned what music is and what it can be, using a piece ostensibly featuring nothing but silence to illustrate his newfound conviction that "in fact, try as we may to make a silence, we cannot" (Cage, 1961, p. 8).

The question for Cage after 4'33" was clear: where could he go from here? While this work opened the door for his indeterminate pieces that followed, 4'33'" swung the pendulum as far as it could go aesthetically, meaning that subsequent indeterminate works could arguably represent only glosses or variants on it (Broyles, 2004, p. 186). Cage then seemed to come full circle in the 1970 s by returning to a role of composer-as-craftsman, revisiting aesthetic notions that he had rejected with the "non-intention-based' aesthetic of 4'33" and his subsequent indeterminate compositions (Pritchett, 1993, pp. 164-175), which was perhaps an indication, as Sharon Williams suggests, that Cage's earlier idealism had by the 1970s become tempered by pragmatism (Williams, 2013, p. 93).

4'33" was thus for Cage a culmination of his early work, a watershed that opened the door to seemingly infinite new possibilities, yet also a point of departure from which no truly new path could be traversed-his only choice was to eventually reaccept some or all of what had been discarded. It can be argued that 4'33" was in fact a seminal turning point not just for Cage but for American music as a whole, what Kyle Gann calls "a kind of death of music that renders a rebirth possible" (Gann, 2006, p. 384). The main factors that led Cage to compose this work are threefold: 1) its inspiration was in part derived from insights realised in a successful earlier composition (Sonatas and Interludes); 2) it represented the natural endpoint of philosophical ideas regarding silence, nothingness and non-possession that had been building for years before; and 3) these bourgeoning philosophical notions were in part crystallized yet in part repudiated by a noteworthy life event (his experience in the anechoic chamber). Cage's fortieth year was thus marked by a confluence of events that profoundly affected and sharply focused his compositional aesthetics, leading to the creation of his signature work - a piece that represented a culmination of his ideas to that point yet simultaneously a clear shift in favour of new directions. 


\section{The Case of Steve Reich (b. 1936)}

\section{Reich on Cage}

Steve Reich is frequently cited as one of the pioneers of musical minimalism, a style of music that at least on the surface seems to have much in common with Cage's music. In fact, Keith Potter posits that 4'33" "must in some sense be regarded as the ultimate minimalist statement" (Potter, 2000, p. 5). Jonathan Bernard cautions, however, that although minimalists may have originally regarded Cage as a sort of kindred spirit, "it can be persuasively argued that the music of chance ultimately served the minimalists as a negative ideal, an example of what not to do" (Bernard, 1993, p. 97). For his part, Reich noted that he "received no satisfaction whatever" from Cage's music, that Cage in fact gave him "something to push against" (Reich, 2002, p. 159). That Reich sought to distinguish his aesthetic ideals from those of Cage should not be interpreted as a lack of respect, however, for Reich recalls that he appreciated Cage's personal integrity and consistency, affirming that Cage "had a vision and followed it with remarkable purity" (Reich, 2002, p. 165). The two composers' career trajectories also parallel each other in notable ways, including the convergence of factors stimulating the completion of their signature works during the years in which they turned forty.

\section{Leading up to 1976}

Reich's early compositional style is frequently associated with the phasing process exemplified in works such as Come Out (1966) and Piano Phase (1967), the aesthetics of which are eloquently captured in his seminal 1968 essay 'Music as a Gradual Process'. In this essay, Reich proclaimed that he was not referring to the compositional process itself, "but rather pieces of music that are, literally, processes", then further clarified that "I want to be able to hear the process happening throughout the sounding music", thereby differentiating himself from Cage as clearly as possible (Reich, 2002, p. 34). It was upon returning from a trip to Ghana, however, that Reich's mature style truly began to take shape with the ensemble work Drumming (completed in 1971 at age 35), which absorbed some of the spirit and techniques of the Ghanaian music that he studied and played.

Drumming is the final expansion and refinement of the phasing process, as well as the first use of four new techniques: 1) the process of gradually substituting beats for rests (or rests for beats); 2) the gradual changing of timbre while rhythm and pitch remain constant; 3 ) the simultaneous combination of instruments of different timbre; and 4) the use of the human voice to become part of the musical ensemble by imitating the exact sound of the instruments. (Reich, 2002, p. 64)

Following a stylistic evolution similar to that of Cage, for Reich this successful earlier composition served as a high-water mark in his aesthetic development to that point yet also paved the way for his signature work, which he would likewise complete about five years later. As Potter affirms, Drumming is "an 
important breakthrough both technically and stylistically ... but it was not until March 1976 that Reich was able to complete Music for Eighteen Musicians, the work which capitalized on these developments and took them forward to an altogether new level" (Potter, 2000, p. 211).

\section{Music for Eighteen Musicians and beyond}

The completion of Music for Eighteen Musicians (completed in 1976, with first sketches dating to 1974) signified a turning point for Reich in a variety of ways. Potter calls it a watershed in part because it marks the end of Reich's interest in minimalism per se (Potter, 2000, pp. 151-152). Paul Hillier agrees with this assessment, arguing that by 1976, using the word 'minimalist' to describe Reich's music was beginning to look "mean-spirited, and worse, misguided" (Hillier, 2002, p. 4). K. Robert Schwarz similarly contends that Music for Eighteen Musicians exemplifies a shift in Reich's music toward greater intuition with less emphasis on process (Schwarz, 1990, p. 246), a position supported by Reich's own remarks that he "made a great deal more choices" in this piece, and that it was "consciously composed with a feeling of liberating [himself] from strict structures" (Nyman \& Reich, 2002, pp. 93-94).

Shortly after finishing the piece, Reich noted that "there is more harmonic movement in the first five minutes of Music for Eighteen Musicians than in any other complete work of mine to this date" (Reich, 2002, p. 87). In addition, he emphasized the piece's striking innovations in the realms of rhythm and temporality, remarking that it simultaneously features two types of rhythm: a regular pulse in the pianos and mallet instruments and the rhythm of the human breath in the voices and wind instruments. Finally, Reich described the novel way in which he exploited the rhythmic relationship between harmony and melody to create change or development as follows.

A melodic pattern may be repeated over and over again, but by introducing a twoor four-chord cadence underneath it, first beginning on one beat of the pattern, and then beginning on a different beat, a sense of changing accent in the melody will be heard. This play of changing rhythm against constant melodic pattern is one of the basic techniques of this piece, and one that I had never used before. Its effect, by change of accent, is to vary that which is in fact unchanging. (Reich, 2002, p. 90)

Music for Eighteen Musicians represents a continuation in the development of Reich's construction of rhythmic patterns by gradually substituting beats for rests and the integration of human voices into an instrumental ensemble, ideas he first explored about five years prior in Drumming. Importantly, however, the piece also exemplifies the new directions in which Reich's music would go afterward. Reich acknowledges that Music for Eighteen Musicians represented a change in the way he composed, recalling that he usually began his early pieces with a melodic pattern, but starting in 1976 he began using harmonic cycles to outline the structure of a piece (Hillier \& Reich, 2002, pp. 217-218). This is a technique Reich would return 
to many times in his subsequent works, including Variations for Winds, Strings, and Keyboards (1979), The Desert Music (1984), Sextet (1985), New York Counterpoint (1985), Three Movements (1986) and Electric Counterpoint (1987).

Music for Eighteen Musicians thus on one hand represented a culmination for Reich of ideas originating in a successful work from about five years before (Drumming). Philosophically, however, the piece's striking innovations and new approaches epitomized Reich's desire to go beyond, or in a sense repudiate, some of his earlier viewpoints, underscoring his declaration that "the artists I admire are the ones that move on" (Nyman \& Reich, 2002, p. 94). Potter notes that the "on-theedge' achievements of Music for Eighteen Musicians initially proved difficult for Reich to sustain or move on from; he completed no works after this for over two years, as "he had lost all compositional momentum and ... was determined not to repeat himself" (Potter, 2000, p. 246). On the other hand, Potter acknowledges that a hiatus of this magnitude "now seems an important part of the work's achievement as well as its historical significance" (Potter, 2000, p. 152). In a notable parallel with Cage, Reich's fortieth year marked the completion of what would become his signature work - a piece simultaneously representing a culmination of ideas drawn from a successful composition about five years prior yet distinctly pointing toward new ideas and new directions.

\section{The Case of John Adams (b. 1947)}

\section{Adams on Cage and Reich}

The career of John Adams has been influenced in no small part by both John Cage and Steve Reich. As Adams worked to find his voice as a composer during college and shortly after graduation, his main inspirational figure was Cage, who he considered "genuinely American and utterly original" (May \& Adams, 2006a, pp. 910). Adams recalls that he was a devoted follower of Cage for about a five-year period in the late 1960s and early 1970s, but even then, despite his interest in Cage's philosophies, he "had to suffer extensive cognitive dissonance over the fact that [he] continued to get [his] emotional highs from Coltrane, Beethoven, Bartók, and Joplin (Janis, not Scott)" (Adams, 2008, p. 59). Before long, Adams began to drift away from Cage's influence, feeling unfulfilled due to his conviction that "without the benevolent presence of Cage himself, the result of all the coin tossing and chance operations was more often than not emotionally cold and expressively indifferent" (Adams, 2008, p. 86).

In 1974, Adams discovered an alternative inspiration in the music of Steve Reich, a composer he greatly admires to this day. Part of what attracted Adams was the elegance and sophistication of Reich's aesthetic.

What also impressed me about Reich's music-making was that it was done at a high level of expertise and preparation. In contrast to the free, anarchic avant-garde 'happenings' I'd been involved with, Reich's music used precision and balanced 
counterpoint to create a sound world that was carefully organised, musically engaging, and sensually appealing. (Adams, 2008, p. 89)

Although Adams did not set out to copy Reich's style per se, the tightness and professionalism of Reich's ensemble performances conveyed a sound world that resonated deeply with him. Adams recalls that the first time he heard Music for Eighteen Musicians, he felt that "the experience of pure aural pleasure, so long absent in contemporary classical music, had re-emerged from a long, dark night of the soul" (Adams, 2008, p. 95). The admiration between the composers is mutual; Reich has stated that "John Adams is a great composer and I am proud to have had even a small influence on his music" (Hillier \& Reich, 2002, p. 233).

\section{Leading up to 1987}

Harmonium, a large-scale work for orchestra and chorus commissioned by the San Francisco Symphony and written in 1980-81 at age 33-34, was the piece that, in the words of Michael Steinberg, "really put John Adams on the map" (Steinberg, 2006a, p. 80). It was in this work that Adams's unique integration of minimalism into a traditional symphonic context first came to fruition. As Alex Ross would later argue, when Adams "began writing serious concert works that drew on minimalist techniques, he showed that classical forms were capable of absorbing almost anything" (Ross, 2006, p. 33).

Interestingly, Adams's relationship to the minimalist style has always been more tenuous than one might infer from reading the preceding paragraphs, however. While Adams found minimalism to be a source of inspiration and absorbed many minimalist elements into his own particular style, he notes that he never felt as closely bound as his predecessors to the processes and strictures of minimalism.

Minimalist procedures pointed to a way. I felt that the classics of the style were ground-breakers for sure, but I also recognised that Minimalism as a governing aesthetic could and would rapidly exhaust itself. Like Cubism in painting, it was a radically new idea, but its reductive world-view would soon leave its practitioners in an expressive cul-de-sac. (Adams, 2008, p. 93)

Adams's reservations did not cause him to reject musical minimalism, but instead he sought ways to incorporate minimalist elements into a more expressive style, exemplified in Harmonium by sudden changes of texture, wide dynamic variations and large-scale formal architectures. Beginning with a minimalistinfluenced repetition of the word 'no', the first movement builds to a number of roaring fortissimos and employs striking harmonic shifts underscoring the meaning of the text. Even the sparser second movement features a noticeable dramatic arc, and the third movement is boldly exuberant. Adams would achieve further success in this vein with the symphonic work Harmonielehre (1984-85), but it was a meeting with an up-and-coming young opera director around the same time that would plant the seeds for his eventual signature work. 


\section{Nixon in China and beyond}

In 1983, Adams met Peter Sellars, who would become artistic director of the American National Theatre in Washington DC shortly thereafter. Sellars, who- like Adams, graduated from Harvard, was familiar with the composer's work, and upon meeting him, proposed that they collaborate on an opera about President Richard Nixon's historic trip to China in 1972. Adams agreed to stay in touch with Sellars but was initially reluctant, wondering "how he could have imagined me, who had never written a note for solo voice, as the ideal composer for such a project beggars understanding" (Adams, 2008, p. 127). Sellars notes, however, that he sought out Adams because after hearing the composer's early instrumental works, he realised that "this is theatre music, which has the ability to build and sustain tension" (May \& Sellars, 2006, p. 239). By late 1985, two years after Sellars's request, Adams finally realised "not only that Nixon in China was a brilliant idea for an opera but that it should be composed by John Adams" (Adams, 2008, p. 128), and he eventually completed the opera in 1987.

Adams ultimately became engrossed in the idea of writing Nixon in China for multiple reasons. First, he was drawn in by the charisma of the main characters, noting that for him "Nixon and Mao virtually embodied the twentieth century's agonistic struggle for human happiness: capitalism versus communism ... The lead characters were so vivid they literally cried out for operatic treatment" (Adams, 2008, p. 136). In addition to admiring Sellars's vision for the opera, Adams marvelled at Alice Goodman's extraordinary libretto, saying that she exhibited "a talent and technique that has nearly vanished from American poetical practice" (Adams, 2008, p. 136). Finally, he found the story itself very attractive, as it offered "the opportunity to move, during the course of three acts, from the plastic cartoon versions of public people that the media is always presenting us with, to the real, uncertain, vulnerable human beings who stand behind these cardboard cut-outs" (Porter \& Adams, 1988, p. 26).

Choosing the musical language for an opera whose aims were to be "both theatrically entertaining and psychologically acute" was quite challenging: in Adams's words it was "a steep learning curve, but I revelled in it" (Adams, 2008, pp. 140-141). The music that Adams ultimately composed featured everything from evocations of minimalism, to big band music from the Swing Era, to Chinese Communist ballets. Adams further notes that the score is "emphatically triadic in a way that no other work of mine ever dared to be", with "Technicolor orchestration" that reflects the influence of gaudy political propaganda (Adams, 2008, p. 144). Despite the many challenges that writing the opera posed, Adams was thankful that he "had the good fortune to understand one important thing even at that young age: that a good opera composer needs to be flexible and must learn to make his musical language capable of the slightest shift of mood or psychology on the part of his characters" (Adams, 2008, p. 144).

Nixon in China is a remarkably innovative opera, one whose subject matter and treatment of its characters have become quite influential in the genre. Steinberg observed just how rare it was for audiences to encounter familiar, living characters 
(all of whom could have conceivably attended the premiere) on the operatic stage (Steinberg, 2006b, p. 110), while Ross further noted that the pioneering treatment of contemporary subjects in Nixon in China set off a trend for what have in some circles become known as 'CNN operas' (Ross, 2006, p. 38). Though Adams makes no secret of his disdain for this label, he acknowledges that writing an opera dealing with current events and issues was such a novel idea in 1987 that it attracted an extraordinary amount of interest from musicians and the media (May \& Adams, 2006b, pp. 229, 234).

Nixon in China was in some ways a grand culmination of what Adams's aesthetic philosophies had been pointing toward since Harmonium: music drawing on minimalist techniques yet replete with changes of mood and a palpable sense of drama. Like Reich, however, Adams found that his signature work also represented a need to keep developing his musical style. For his next opera, The Death of Klinghoffer (1991), in which he again collaborated with Sellars and Goodman, Adams realised that this opera's darker subject matter meant he could not use the same 'brightly-coloured', triadic musical language he employed in Nixon in China, stating that "I discovered how composing for the operatic stage could have a hugely beneficial effect on the evolution of a composer's musical language" (Adams, 2008, p. 171). Indeed, his subsequent stage productions, such as El Niño (2000) and Doctor Atomic (2005), have further witnessed Adams pushing his musical language in new directions, becoming progressively less influenced by minimalism and embracing a broader harmonic palette that includes darker shades rarely heard in his music before Nixon in China. Like Cage and Reich before him, Adams's fortieth year was therefore the apex of developments spurred by a successful composition from about five years prior (Harmonium), yet simultaneously a turning point marking a substantial change in his style. In Adams's case, this evolution was prompted by the unique challenge of writing for the operatic stage.

\section{Implications and conclusions}

John Cage, Steve Reich and John Adams all completed their signature works in the years in which they turned forty, an intriguing age-related correspondence precisely corroborating Simonton's finding that composers' fortieth years tend on average to function as a focal point of creative output. Studying these three composers' overall career arcs from this perspective reveals some other notable parallels as well. Each composer's signature work can be meaningfully traced to ideas originating in a successful piece written around five years beforehand: Cage's 4'33" (1952) derives in part from Sonatas and Interludes (1946-48); Reich's Music for Eighteen Musicians (1974-76) expands upon some ideas from Drumming (1971); and aspects of Adams's Nixon in China (1985-87) first took root in Harmonium (1980-81). Each composer's signature work can also be conceived as a natural outgrowth of his aesthetic developments in the years leading up to the composition. Intriguingly, however, in all three cases, the composer's signature work also represented a sort of repudiation or reconsideration of compositional aesthetics developed up to that point. In other words, the composers' signature works served not only as a 
culmination of previous ideas but simultaneously marked a significant turning point in their respective careers.

In light of the remarkable parallels observed in this study of Cage, Reich and Adams, there are a few factors that may merit further investigation in exploring the significance of age forty with regard to composers' creation of their signature works. Future research could focus on how cultural dynamics and major historical events may at times influence when individual composers are likely to create their signature works and what works critics and audiences are likely to perceive as landmarks. In addition, the determination of a composer's signature work seems to at least partially require the retrospective judgment of history, meaning that such appraisals are not always immutable.

In spite of the aforementioned challenges, the studies of Cage, Reich and Adams presented in this article illustrate how considering the significance of age forty in relation to the composers' signature works stimulates close examination of their overall output, which in turn provides valuable insights into the composers' aesthetics and the forces that shaped their development. Exploring the careers of Cage, Reich and Adams from this perspective also emphasizes mutual connections and influences among the three composers and sheds light on the confluence of factors that made their fortieth years so pivotal, indicating that this approach offers an intriguing and fruitful avenue of inquiry into the composers' career arcs and stylistic evolution.

\section{References}

Adams, J. (2008). Hallelujah junction: Composing an American life. New York, NY: Farrar, Straus, and Giroux.

Beard, G. M. (1874). Legal responsibility in old age. New York, NY: Russell Sage Foundation.

Bernard, J. (1993). The minimalist aesthetic in the plastic arts and in music. Perspectives of New Music, 31, 86-132.

Bernstein, D. (2002). Music I: To the Late 1940s. In D. Nicholls (Ed.), The Cambridge Companion to John Cage (63-84). Cambridge: Cambridge University Press.

Broyles, M. (2004). Mavericks and other traditions in American music. New Haven and London: Yale University Press.

Cage, J. (1961). Silence. Middletown, CT: Wesleyan University Press.

Cage, J. (1967). A year from Monday. Middletown, CT: Wesleyan University Press.

Dennis, W. (1966). Creative productivity between the ages of 20 and 80 years. Journal of Gerontology, 21, 1-8.

Gann, K. (2006). American music in the Twentieth Century. Mason, OH: Cengage Learning.

Hillier, P. (2002). Introduction. In P. Hillier (Ed.), Steve Reich, Writings on music, 19652000 (3-18). Oxford: Oxford University Press.

Hillier, P., \& Reich, S. (2002). Steve Reich in conversation with Paul Hillier. In P. Hillier (Ed.), Steve Reich, Writings on music, 1965-2000 (216-241). Oxford: Oxford University Press.

Lehman, H. C. (1953). Age and achievement. Princeton, NJ: Princeton University Press.

May, T. (2006). Introduction. In T. May (Ed.), The John Adams reader: Essential writings on an American composer (xiii-xviii). Pompton Plains, NJ: Amadeus Press. 
May, T., \& Adams, J. (2006a). John Adams reflects on his career. In T. May (Ed.), The John Adams reader (2-28). Pompton Plains, NJ: Amadeus Press.

May, T., \& Adams, J. (2006b). John Adams on Doctor Atomic. In T. May (Ed.), The John Adams reader (219-236). Pompton Plains, NJ: Amadeus Press.

May, T., \& Sellars, P. (2006). Creating contexts: Peter Sellars on working with Adams. In T. May (Ed.), The John Adams reader (238-248). Pompton Plains, NJ: Amadeus Press.

Nicholls, D. (2007). John Cage. Urbana and Chicago: University of Illinois Press.

Nyman, M., \& Reich, S. (2002). Second interview with Michael Nyman. In P. Hillier (Ed.), Steve Reich, Writings on Music, 1965-2000 (91-97). Oxford: Oxford University Press.

Porter, A., \& Adams, J. (1988). 'Nixon in China': John Adams in conversation. Tempo, 167, $25-30$.

Potter, K. (2000). Four musical minimalists: LaMonte Young, Terry Riley, Steve Reich, Philip Glass. Cambridge: Cambridge University Press.

Pritchett, J. (1993). The music of John Cage. Cambridge: Cambridge University Press.

Reich, S. (2002). Writings on music, 1965-2000. P. Hillier (Ed.). Oxford: Oxford University Press.

Ross, A. (2006). The harmonist. In T. May (Ed.), The John Adams reader (29-44). Pompton Plains, NJ: Amadeus Press.

Schwarz, K. R. (1990). Process v. intuition in the recent works of Steve Reich and John Adams. American Music, 8, 245-273.

Simonton, D. K. (1988). Age and outstanding achievement: What do we know after a century of research? Psychological Bulletin, 104 (2), 251-267.

Simonton, D. K. (1991). Emergence and realization of genius: The lives and works of 120 Classical Composers. Journal of Personality and Social Psychology, 61 (5), 829840.

Steinberg, M. (2006a). Harmonium for large orchestra and chorus. In T. May (Ed.), The John Adams reader (80-88). Pompton Plains, NJ: Amadeus Press.

Steinberg, M. (2006b). Nixon in China. In T. May (Ed.), The John Adams reader (110-119). Pompton Plains, NJ: Amadeus Press.

Whittington, S. (2013). Digging in John Cage's garden: Cage and Ryōanji. Malaysian Music Journal, 2 (2), 12-21.

Williams, S. (2013). Uncaged: John Cage and conceptual approaches to participatory musicmaking. Malaysian Music Journal, 2 (2), 90-103.

\section{Biography}

Kyle Fyr is the musicology department chair and the Master of Arts program chair at the College of Music, Mahidol University (Thailand). He received a $\mathrm{PhD}$ in music theory with doctoral minors in music history and piano performance from the Indiana University Jacobs School of Music in 2011, writing a dissertation focusing on proportionality and performance issues in piano works of John Adams. From 2011-13, he was an Assistant Professor of Music Theory at the University of Northern Colorado. He has presented papers at a variety of conferences throughout the US and UK, and has published in the journals Music Theory Online and Notes. 